\title{
Molecular and Pathological Analysis of Chicken Anemia Virus Isolated from Field Infection in Three Egyptian Provinces
}

\author{
Eid Hussein ${ }^{1}$, Abd El-Satar Arafa ${ }^{2 *}$, Nesrin Anwar ${ }^{1}$, Asmaa Khafaga ${ }^{3}$
}

\begin{abstract}
${ }^{1}$ Reference Laboratory for Veterinary Quality Control on Poultry Production, Damanhour Branch, Egypt; ${ }^{2}$ Reference Laboratory for Veterinary Quality Control on Poultry Production, Dokki, Giza, Egypt; ${ }^{3}$ Pathology Department, Faculty of Veterinary Medicine, Alexandria University, Egypt.
\end{abstract}

\begin{abstract}
Chicken anemia virus (CAV) is a ubiquitous pathogen of chickens causing economically important disease in commercial flocks, around the globe. The present study was designed to assess the epidemiological, molecular and pathological characteristics of CAV from field infections in forty unvaccinated commercial broiler flocks in three Egyptian provinces. Important clinical features such as stunting, depression and mortalities ranged from 3-31.25\% were observed. Post-mortem examination revealed pale liver, enlarged spleen and severe thymus and bursal atrophy; whilst, the major histopathologic findings were lymphoid depletion and focal hepatic necrosis. The characteristic apoptotic patterns were confirmed using TUNEL assay. Moreover, a serologic survey was performed using ELISA assay to detect CIA virus (CAV)-specific antibody. A total of $85 \%$ of the examined flocks was found seropositive while, CAV DNA was detected in $65 \%$ of the examined flocks using PCR. The phylogenetic analysis of two Egyptian CAVs indicated their grouping close to viruses previously reported from China and the Middle East. The characterized viruses were distinct from viruses recently reported from Egypt and from rest of the Africa. Furthermore, genetic matching indicated that circulating CAVs in Egypt carry marked variations compared to a commercial CAV vaccine strain (Nobilis ${ }^{\circledR}$ CAV P4) and old Egyptian CAV isolates of 1990s. Taken together, the present study highlights the significance of CAV in Egypt and proposes further studies to systemically compare the genetic divergence and vaccine matching. These findings are fundamental in any effort to control avian pathogens in the country.
\end{abstract}

Keywords | Chicken Anemia Virus, PCR, Apoptosis, Histopathology, Broiler

Editor | Kuldeep Dhama, Indian Veterinary Research Institute, Uttar Pradesh, India.

Received | April 18, 2016; Accepted | May 10, 2016; Published | May 18, 2016

*Correspondence | Abd El-Satar Arafa, Reference laboratory for veterinary Quality control on poultry production, Dokki, Giza, Egypt; E-mail: arafaweb@ yahoo.com

Citation | Hussein E, Arafa AE, Anwar N, Khafaga A (2016). Molecular and pathological analysis of chicken anemia virus isolated from field infection in three Egyptian Provinces. Adv. Anim. Vet. Sci. 4(5): 218-229.

DOI | http://dx.doi.org/10.14737/journal.aavs/2016/4.5.218.229

ISSN (Online) | 2307-8316; ISSN (Print) | 2309-3331

Copyright (C) 2016 Hussein et al. This is an open access article distributed under the Creative Commons Attribution License, which permits unrestricted use, distribution, and reproduction in any medium, provided the original work is properly cited.

\section{INTRODUCTION}

$I^{\prime}$ nfectious diseases cause major economic losses in the poultry industry and these losses are attributed to high mortalities, reduced production and cost for preventive medications. One of these infectious diseases is chicken infectious anemia (CIA). CIA is caused by the chicken infectious anemia virus (CAV) and it was first reported in Japan in 1979 in specific-pathogen free (SPF) chicks (Hussein et al., 2002). Several previous studies reported that CIAV is a small, non-enveloped, icosahedral virus and it consists of single negative-stranded circular DNA genome with average diameter measuring 25-26.5 nm (Pringle, 1999; Schat, 2003). The viral genome consists of 2.3 kilobases, with three partially overlapping open reading frames (McConnell et al., 1993) encoding three viral proteins namely VP1, VP2 and VP3. VP1 (the major viral structural protein, $51.6 \mathrm{kDa}$ ) and VP2 (a novel dual-specificity protein phosphatase, $24 \mathrm{kDa}$ ) are the targets of neutralizing antibodies (Peters et al., 2001). While, VP3 (a non-structural protein named apoptin, $13.6 \mathrm{kDa}$ ) induce apoptosis in thymic lymphoblasts, intra- and extra-sinusoidal hemocytoblasts, and reticular cells (Noteborn et al., 1991; Noteborn et al., 1994; Noteborn et al., 1998). Fur- 
thermore, CAV has been recognized as a single serotype on the basis of virus neutralization assays with polyclonal antibodies (Adair, 2000; McNulty et al., 1991; Yuasa and Imai, 1986). Three genetically distinct genotypes (I, II, and III) have been recognized in classical CAV based on the phylogenetic analysis of the VP1 gene (Craig et al., 2009; Ducatez et al., 2008; Ducatez et al., 2006; Islam et al., 2002; Kim et al., 2010; Snoeck et al., 2012). Genotypes II and III are reported to be distributed worldwide, whereas genotype $\mathrm{I}$ is composed solely of isolates from Australia (Kim et al., 2010). Infections occurring between one and four days of age result in clinical symptoms and lesions, observed mainly in 2 to 4 -week-old flocks (Dhama et al., 2002; Senthilkumar et al., 2002; Todd, 2000). Outbreaks of the disease are characterized by anemia, thymus atrophy, bone marrow aplasia, hemorrhages and general immunosuppression (Lucio et al., 1990; Yuasa et al., 1987). However, dual infections are more severe due to secondary infections (Dhama et al., 2002; McNulty et al., 1991; Pope, 1991; Todd, 2000). Moreover, infection with CAV is causing depression of immune response against vaccine of several 80 viruses such as NDV, MDV, ILTV and FPV leading to vaccination failures, vaccination reactions, aggravation of the residual pathogenicity of attenuated vaccine viruses and emergence of variant virus (Dhama et al., 2002; Todd, 2000; Van Den Berg, 1996). Chickens older than 2-3 weeks of age are also susceptible to infection, but will only develop a subclinical disease resulting in immunosuppressive effects (Schat, 2003). Several pathological studies have been assigned for CAV naturally and experimentally infected chicks (Biilow et al., 1986; Goryo et al., 1987; Smyth et al., 1993). The detected lesions are consistent reduction and destruction of erythrocytic and granulocytic series of the bone marrow cells resulting in aplastic anemia. Moreover, lymphocytic depletion, necrosis and apoptosis in lymphoid organs such as thymus, bursa, spleen and caecal tonsils were detected (Taniguchi et al., 1982). However, rare and transient intranuclear inclusion bodies were reported in both thymus and bone marrow but are of limited diagnostic value (Pope, 1991). Normally, the virus does not grow in any of the commonly used primary cells and cell lines. Marek's disease virus or avian leucosis virus transformed lymphoblastoid cell lines are susceptible to this virus and the virus usually multiplies with low titre (Natesan et al., 2006). For this reason, different molecular diagnostic methods have been developed for CAV diagnosis, out of which polymerase chain reaction ( $\mathrm{PCR}$ ) seems to be the fastest and most sensitive method for the detection of virus nucleic acid (Jeurissen et al., 1992). Isolation of the virus has been reported in major poultry-producing countries worldwide (Oluwayelu et al., 2005). The virus was isolated from chickens in Japan, China, Australia, New Zealand, India, Slovenia, Brazil and South Africa (Schat, 2003). In Egypt, previous investigator (Hussein et al., 2002) used
PCR for molecular diagnosis of CAV where they detected a 418 base pair (bp) CAV-specific band in blood and tissue samples from infected broiler breeder chicks. However, few studies are available about the chicken anemia viruses circulating in chicken population in Egypt (El-Lethi, 1990; Hegazy et al., 2010; Sabry et al., 1998; Zaki and El-Sanousi, 1994) and no information are available on the incidence of CIAVs circulating in the commercial broiler flocks in El-Behera, Matrouh and Kafr El-Sheikh province. Therefore, the current study was undertaken to assess the incidence of CAV in three provinces through seroprevalence, molecular and pathological analysis of CAV that are circulating in the field. The findings of the study highlight the importance of CAV as emerging avian pathogen in studied Egyptian provinces, which would be fundamental in devising suitable control strategies for the disease.

\section{MATERIALS AND METHODS}

\section{History}

During a period of 2014-2015, a total of 40 broiler chicken flocks were submitted to National Laboratory for Quality Control on Poultry Production (NLQP), Damanhur branch, Egypt. Flocks ranged in age from 22 to 43 days representing different breeds (25 Cobb, 8 avian-48, 4 Ross and 3 Arbor Acres) localized in E1-Behera, Matrouh and Kafr El-Sheikh provinces and farm capacity ranged from 2000-8500 birds. None of the farms vaccinated against CAV.

\section{Tissue Samples}

Thymus, liver, spleen, bursa of Fabricius and bone marrow samples were collected aseptically from sacrificed birds $(n=5)$ and were subjected to clinical and post-mortem examinations.

\section{Serum Samples}

Ten serum samples were collected from each of the 40 commercial broiler flocks and were stored at $-70^{\circ} \mathrm{C}$ until used to study of the seroprevalence of CAV in broiler flocks using ELISA.

\section{Detection of CAV Antibodies by ELISA}

Commercial CAV antibodies ELISA test kit (ProFLOk PLUS, Synnbiotics Corporation, San Diego, CA, USA; Cat. No. 92127-800-228-4305) was used according to the manufacturer instructions.

\section{Histopathology}

Small specimens of liver, bursa of Fabricius, thymus, bone marrow and spleen were collected from sacrificed chicks then immediately fixed in 10\% neutral phosphate buffered formalin for 24 hours. After fixation, tissues were processed through the conventional paraffin embedding technique 
Table 1: seroprevalence of chicken anemia infectious virus in commercial broiler chicken flocks in three Egyptian provinces

\begin{tabular}{|c|c|c|c|c|c|c|}
\hline $\begin{array}{l}\text { Criteria } \\
\text { Serial } \\
\text { farm No }\end{array}$ & Locality and year & Breed & $\begin{array}{l}\text { Age } \\
\text { (days) }\end{array}$ & $\begin{array}{l}\text { Positivity } \\
\text { (\%) }\end{array}$ & $\begin{array}{l}\text { Geometric } \\
\text { mean titer } \\
\text { (GMT) }\end{array}$ & $\begin{array}{l}\text { Coefficient } \\
\text { of variation } \\
\text { (C.V) \% }\end{array}$ \\
\hline 1 & Elmahmoudiah, El-Behera 2014 & Avian-48 & 43 & 90 & 2037 & 42.41 \\
\hline 2 & Disuq, Kafr El-Sheikh 2014 & Ross & 42 & 100 & 5448 & 50 \\
\hline 3 & Hosh Essa, EL-Behera.2014 & Arbor Acres & 34 & 90 & 1519 & 79 \\
\hline 4 & EL Delengat, El-Behera.2014 & Cobb & 30 & 100 & 4593 & 58 \\
\hline 5 & Disuq, Kafr El-Sheikh 2014 & Cobb & 36 & 80 & 825 & 71 \\
\hline 6 & Disuq, Kafr El-Sheikh 2014 & Cobb & 42 & 100 & 4870 & 65 \\
\hline 7 & Disuq, Kafr El-Sheikh 2014 & Cobb & 38 & 80 & 1420 & 69 \\
\hline 8 & Disuq, Kafr El-Sheikh 2014 & Avian-48 & 32 & 100 & 8276 & 52 \\
\hline 9 & Edko, El-Behera 2014 & Cobb & 32 & 100 & 6536 & 37 \\
\hline 10 & Koom El-frag, Abou El matamer, El-Behera 2014 & Cobb & 35 & 90 & 2284 & 51 \\
\hline 11 & Hosh Essa, El-Behera 2014 & Ross & 43 & 90 & 1791 & 34 \\
\hline 12 & Koom El-frag, Abou El matamer, El-Behera 2014 & Avian-48 & 35 & 80 & 874 & 79 \\
\hline 13 & Elmahmoudiah, El-Behera 2014 & Cobb & 30 & 100 & 3405 & 80 \\
\hline 14 & Elmahmoudiah, El-Behera 2014 & Cobb & 43 & 60 & 2396 & 58 \\
\hline 15 & Kafr Eldawwar, El-Behera 2014 & Cobb & 30 & 60 & 1767 & 92 \\
\hline 16 & Koom El-frag, Abou El matamer, El-Behera 2014 & Cobb & 34 & 80 & 621 & 93 \\
\hline 17 & ElDelengat, El-Behera 2014 & Cobb & 32 & 80 & 1825 & 70 \\
\hline 18 & EIDelengat, El-Behera 2014 & Cobb & 31 & 100 & 4623 & 51 \\
\hline 19 & Badr, El-Behera 2014 & Cobb & 41 & 80 & 1760 & 52 \\
\hline 20 & Kom Hamadah, El- Behera 2014 & Cobb & 28 & 80 & 2760 & 58 \\
\hline 21 & El Nagalaa, Matrouh 2014 & Cobb & 43 & 100 & 4560 & 52 \\
\hline 22 & El Nagalaa- Matrouh 2014 & Avian-48 & 32 & 100 & 3105 & 80 \\
\hline 23 & Damanhour, El-Behera 2014 & Cobb & 41 & 100 & 2400 & 60 \\
\hline 24 & Damanhour, El-Behera 2014 & Avian-48 & 42 & 90 & 1364 & 52 \\
\hline 25 & Damanhour, E1-Behera 2014 & Cobb & 35 & 100 & 2750 & 58 \\
\hline 26 & Kafr Eldawwar, El-Behera 2014 & Cobb & 41 & 60 & 132 & 60 \\
\hline 27 & ElDelengat, El-Behera 2014 & Cobb & 34 & 100 & 13878 & 54 \\
\hline 28 & Matrouh 2014 & Avian-48 & 32 & 100 & 3400 & 52 \\
\hline 29 & Koom El-frag, Abou El matamer, El-Behera 2014 & Cobb & 32 & 0 & Negative & 0 \\
\hline 30 & Koom El-frag, Abou El matamer, El-Behera 2014 & Avian-48 & 42 & 60 & 136 & 94 \\
\hline 31 & Koom El-frag, Abou El matamer, El-Behera 2014 & Cobb & 28 & 0 & negative & 0 \\
\hline 32 & Matrouh, 2014 & Avian-48 & 35 & 0 & negative & 0 \\
\hline 33 & Etay ElBaroud,El-Behera 2014 & Arbor Acres & 22 & 20 & 882 & 41 \\
\hline 34 & Koom El-frag, Abou El matamer, El-Behera 2014 & Cobb & 26 & 0 & negative & 0 \\
\hline 35 & Abou El matamer, El-Behera 2014 & Cobb & 33 & 0 & negative & 0 \\
\hline 36 & Kafr Eldawwar, El-Behera 2015 & Arbor Acres & 32 & 0 & negative & 0 \\
\hline 37 & Abou El matamer, El-Behera2015 & Ross & 43 & 70 & 231 & 50 \\
\hline 38 & Koom El-frag, Abou El matamer, El-Behera 2015 & Cobb & 35 & 60 & 53 & 82 \\
\hline 39 & Abou El matamer, El-Behera 2015 & Cobb & 28 & 60 & 682 & 142 \\
\hline 40 & Abou El matamer, El-Behera 2015 & Ross & 42 & 100 & 3931 & 42 \\
\hline
\end{tabular}

(dehydration through ascending serious of ethanol, clear- wax at $60^{\circ} \mathrm{C}$ ) according to the method described by Baning in three changes of xylene and embedding in paraffin croft et al. (1996). Sections of $5 \mu$ thickness were prepared 
and stained with Mayer's Hematoxylin and Eosins (H\&E), and were examined under light microscope to obtain representative photomicrograph for the collected tissues.

\section{Detection of TUNEL Positive Cells}

TUNEL (Terminal deoxynucleotidyl transferase dUTP nick end labelling) assay is a common method for detection of DNA fragmentation, which resulted from apoptotic signalling cascades. This assay relies on the presence of nicks in the DNA, which can be identified by terminal deoxynucleotidyl transferase (TdT), an enzyme that will catalyse the addition of dUTPs that are secondarily labelled with a marker, as previously described by Gravrieli et al. (1992). The apoptotic cells were visualized under light microscopy as a dark brown colour; other non-reactive cells were counterstained to gives a blue shade.

\section{Detection of CAV by PCR}

Tissues preparation: Collected tissue samples were ground with a mortar and pestle in PBS with addition of antibiotic mixture (1000 I.U. penicillin/ml + $1 \mathrm{mg}$ streptomycin sulphate $/ \mathrm{ml}$ ) to prepare a $20 \%$ tissue homogenate. Freezing and thawing were applied three times and then the homogenates were centrifuged at $3000 \mathrm{rpm}$ for $20 \mathrm{~min}$. The supernatant was stored at $-153^{\circ} \mathrm{C}$ until further use for DNA isolation.

PCR for detection of CAV in infected tissues: DNA was extracted from examined tissue homogenates using QIAamp DNA extraction kit (Qiagen, Germany Cat. No 51304). The primers (F: 5'-CTA AGA TCT GCA ACT GCG GA-3' and R: 5'-CCT TGG AAG CGG ATA GTC AT-3') were used to amplify a fragment of $418 \mathrm{bp}$ of CAV genome. PCR was carried out as previously described (Hussein et al., 2002). A total volume of $50 \mu \mathrm{l} \mathrm{PCR}$ reaction containing $5 \mu \mathrm{l}$ of the extracted DNA and $45 \mu \mathrm{l}$ of PCR reaction mixture containing $1 X$ PCR buffer, $0.2 \mathrm{mM}$ of each primer $\mathrm{F}$ and $\mathrm{R}, 200 \mu \mathrm{M}$ of dNTPs mix, 1.25 units of Taq polymerase in a PCR master mix (Thermo, Germany Cat. No K0171). Following an initial cycle at $95^{\circ} \mathrm{C}$ for 3 min, 50 cycles of $95^{\circ} \mathrm{C}$ for $30 \mathrm{sec}, 50^{\circ} \mathrm{C}$ for $30 \mathrm{sec}$ and $72^{\circ} \mathrm{C}$ for $30 \mathrm{sec}$ were conducted. The amplification products were analysed by electrophoresis on $1.5 \%$ agarose gels, stained by ethidium bromide, examined under transluminator and the size of the PCR products were confirmed by visualization on an ethidium bromide stained agarose against DNA
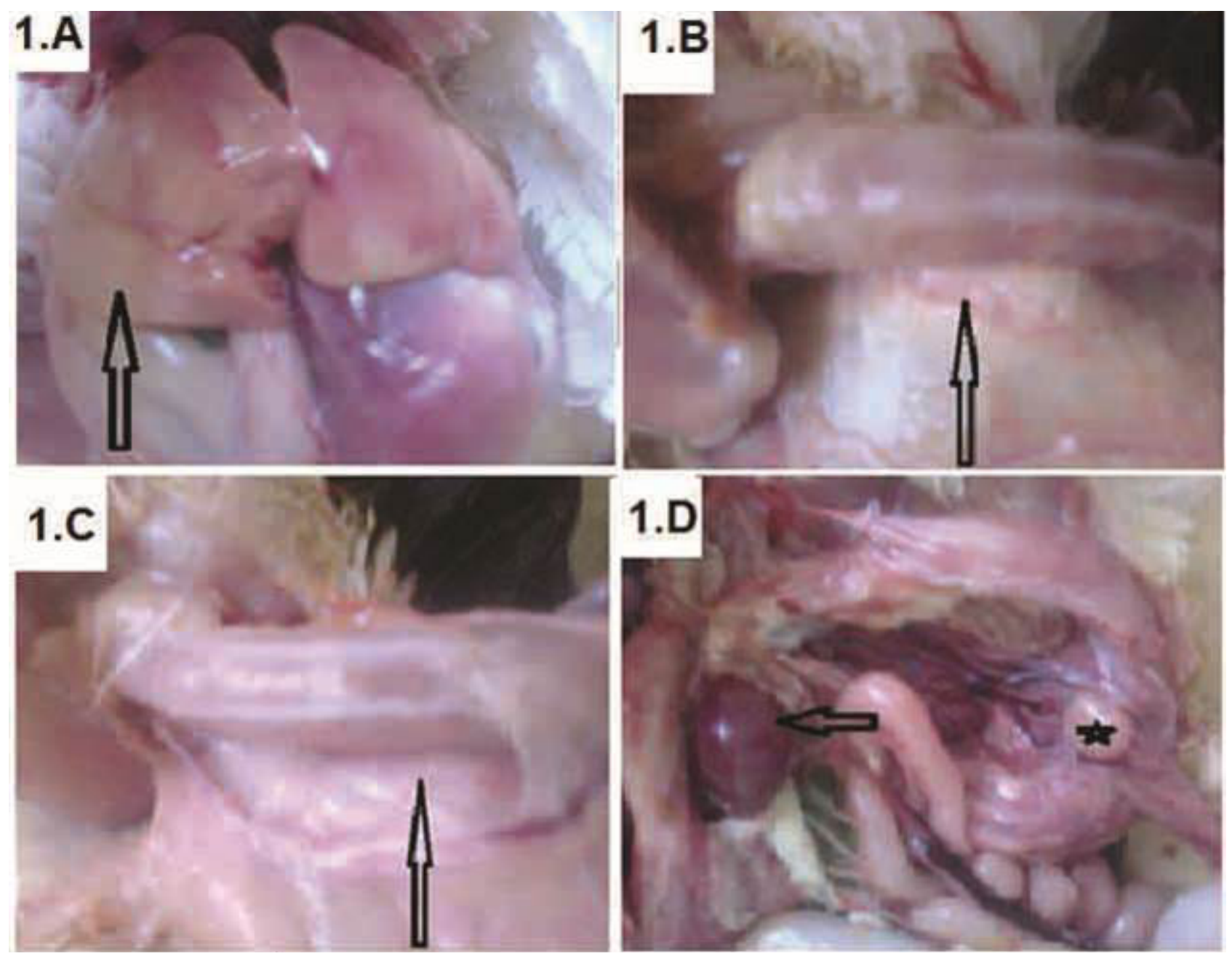

Figure 1: Broiler chickens infected with CAV showed pale liver (A-arrow); Atrophied thymus (B-arrow) sometimes resulting in an almost complete absence of thymic lobes (C-arrow), Enlarged spleen (D-arrow) and atrophied bursa of Fabricius (D-star) 
ladder (GelPilot ${ }^{\circledR} 1$ kb Ladder, Qiagen, Germany, Cat. No. 23908).

Sequencing of VP1 gene and phylogenetic analysis: Gel containing DNA band of the expected size (418bp) was excised and purified with the QIAquick ${ }^{\circledR}$ Gel Extraction Kit (Qiagen, Germany) according to the manufacturer instructions. The purified PCR products were sequenced directly using the ABI PRISM ${ }^{\circledR}$ BigDye $^{\circledR}$ Terminators v3.1 Cycle Sequencing Kit (Applied Biosystems, Foster City, CA, USA) and the ABI PRISM ${ }^{\circledR} 3130$ genetic analyzer (Applied Biosystems) with $80 \mathrm{~cm}$ capillaries. The sequences were edited with SeqScape ${ }^{\circledR}$ Software Version 2.5 (Applied Biosystems), assembly of the consensus sequences and alignment trimming was performed with the Lasergene DNASTAR group of programs (DNASTAR Inc., Madison, WI), using Clustal W method. The phylogenetic tree was drawn using MEGA6 software with other representative viruses from the GenBank and in comparison with other Egypt and international strains. Finally, the percentage identity and divergence between all viruses was

\section{RESULTS}

\section{Epidemiological Data}

During the period of 2014-2015, a total number of 40 suspected CAV affected farms were investigated in three Egyptian provinces (El-Behera, Matrouh and Kafr E1Sheikh) and the obtained data were presented in Table 1. The owners complaints were generally restricted in depression, increased susceptibility to various diseases, vaccination failure and mortalities rate ranged from 3\%-31.25\%.

\section{Clinical Signs and PM Lesions}

Chicks showed signs of anemia, depression, droopy appearance, pale comb and wattles, stunting and growth retardation. The necropsy findings were watery blood, yellow fatty bone marrow, pale liver (Figure 1A) and severely atrophied thymic lobes (Figure 1B), which sometimes resulting in almost complete absence of thymic lobes (Figure 1C). Moreover, enlarged spleen (Figure 1D) and atrophied
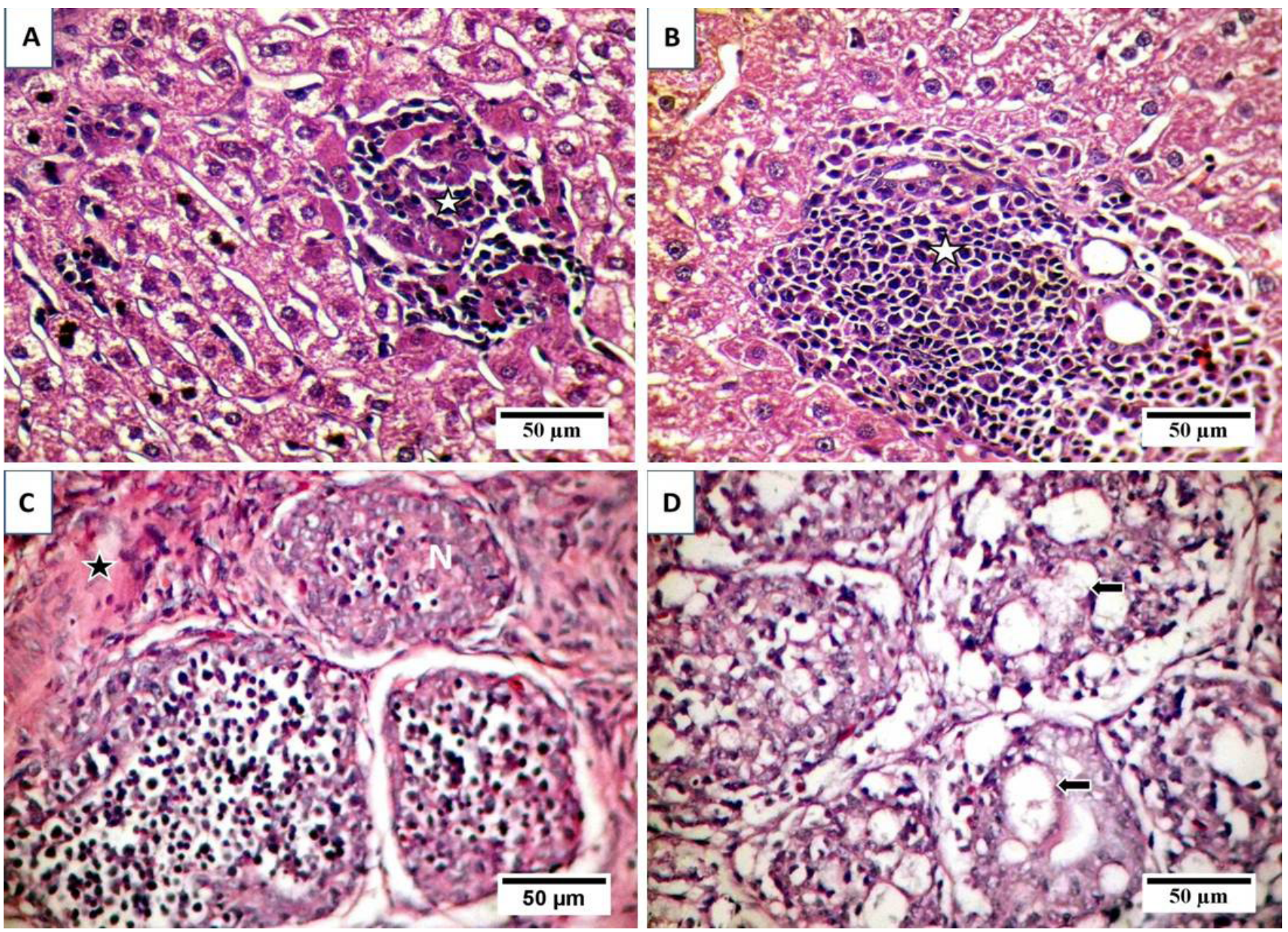

Figure 2: Effect of CIAV on liver (A and B) and bursa (C and D); stained with HE

A) Focal area of coagulative necrosis infiltrated with lymphocytic cells aggregations (stars); B) Portal aggregation of chronic inflammatory cells mainly lymphocytes (star) and mild degeneration of hepatocytes; C) Atrophy and necrosis in the lymphoid follicles (N), indistinct boundary between cortex and medulla and widened interfollicular space filled up by fibrous tissues (star); D) necrosis and cystic cavitation in the lymphoid follicles (arrows). 


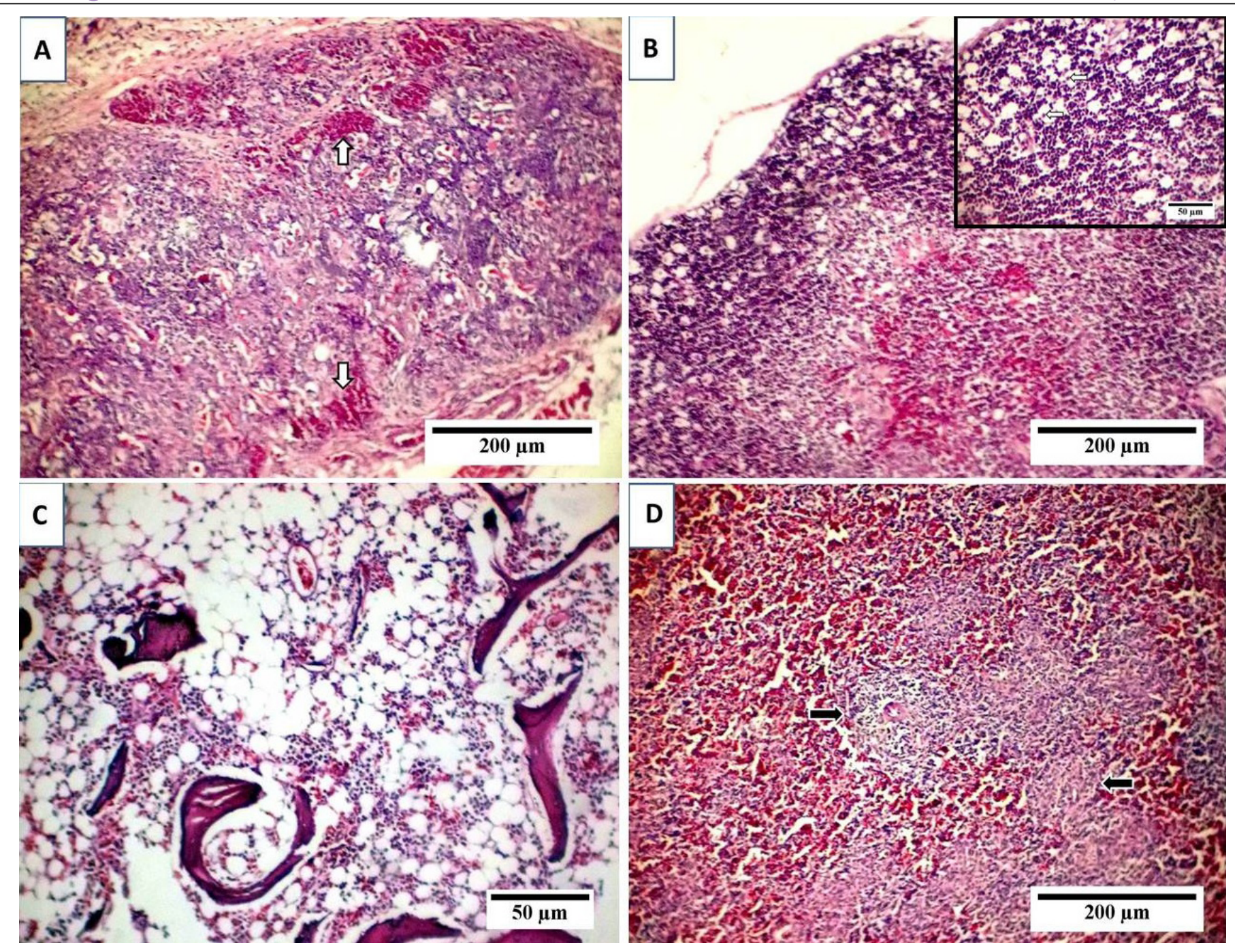

Figure 3: Effect of CIAV on thymus (A, B), bone marrow (C), and spleen (D), stained with HE

A) Thymus with depletion and necrosis of thymocytes, indistinct boundary between cortex and medulla and interfollicular hemorrhage (arrows); B) Starry sky appearance of thymic cortex with free or macrophage containing apoptotic bodies (arrows, inset); C) Marked depletion of hematopoietic cells with lipocytes replacement; D) Lymphocytic depletion of splenic whit Pulp with reticular hyperplasia (arrows).

bursa of Fabricius (Figure 1D) was detected. Some chicks also shown subcutaneous and intramuscular haemorrhages.

\section{Serological Survey by ELISA}

As shown in Table 1, out of 40 broiler chicken flocks serum samples tested for the presence of CAV specific antibodies, 34 broiler chicken flocks serum samples were positive (85\%). For each flock, ELISA geometric mean titers (GMT) ranging from 53 to 13878 ProFLOk PLUS units, positivity percentage ranged from 10 to 100 and coefficient of variation (C.V).

Histopathological Study and TUNEL Positive Cells Confirmation

Examination of liver sections revealed moderate hepatic degeneration, apoptotic bodies formation, focal area of $\mathrm{co}^{-}$ agulative necrosis and focal lymphoid aggregations within the necrotic area (Figure 2A). Furthermore, dilated sinusoid, scattered hepatic and periportal haemorrhage and portal aggregations of mononuclear inflammatory cells predominantly lymphocytes were detected (Figure 2B). Regarding bursa of Fabricius, it showed extensive lymphoid

damages with atrophy in almost all the lymphoid follicles and lymphocytic depletion and necrosis. Moreover, there were indistinct boundary between cortex and medulla and widened interfollicular space filled up by fibrous tissues (Figure 2C). Beside the above-mentioned lesions, numerous apoptotic bodies and cystic cavities in the medullary area were observed (Figure 2D). The microscopic picture of the thymus reflects severe atrophy with depletion and necrosis of thymocytes and indistinct boundary between cortex and medulla (Figure 3A). Furthermore, starry sky appearance of thymic cortex (macrophage containing apoptotic bodies) was detected (Figure 3B). Moreover, bone marrow showed marked depletion of hematopoietic cells including erythrocytic and granulocytic series with noticeable replacement by lipocytes (Figure 3C). However, the 

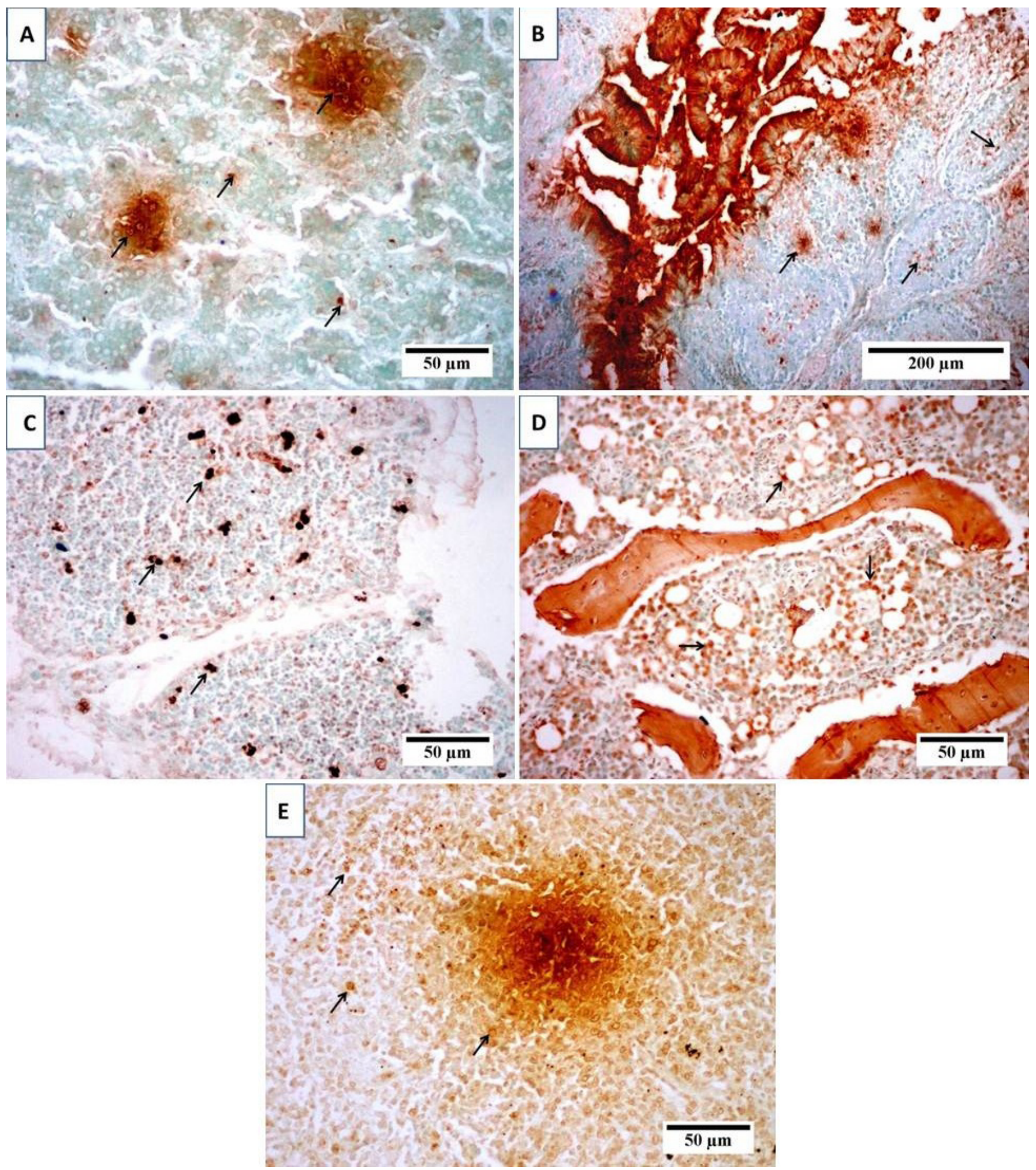

Figure 4: Terminal deoxynucleotidyl transferase-mediated dUTP nick end labeling -(TUNEL) positive cells in (A) liver, (B) bursa, (C) thymus, (D) bone marrow and (E) spleen of broiler chicks infected with CIAV. Photomicrographs show variable levels of apoptosis in different organs. Brown staining indicates TUNEL-positive cells (arrows). Tissues were counterstained with hematoxylin.

sections from spleen showed lymphocytic depletion with reticular hyperplasia (Figure 3D). TUNEL assay was used to clarify the presence of apoptotic cells induced by CAV in different examined organs. Results revealed positive presence of abundant apoptotic cells in almost all the examined sections. These cells are indicated by dark brown colour. The blue shade indicates non-reactive cells stained with counterstain (Figure 4).

Analysis of DNA and the Phylogenetic Tree Analysis of PCR amplification of the extracted DNA from tissue samples by agarose gel electrophoresis indicated 
OPEN OACCESS

DNA bands of corrected size as expected with a length of 418 bp (Figure 5) in 65\% of investigated broiler chicken flocks. The phylogenetic tree for the 2 Egyptian CAV in this study with other CAV strains indicate grouping of Egyptian viruses in one group very close to other viruses from China and Middle East, they are distinct from recent viruses from Egypt and other viruses from Africa like Central African Republic viruses (CAF09-116: HE663030 and CAF09-125: HE663036). The nucleotide divergence of the two Egyptian CAV in this study was shown in Table 2 and Figure 6, the 2 viruses were very close to each other with only $1 \%$ difference ( $99 \%$ identity), while they were apart from old CAV isolated in 1990s, recent Egyptian viruses Egy-1 and Egy-2 (AboElkhair et al., 2014) and with the vaccine strain (Nobilis ${ }^{\circledR}$ CAV P4) with up to $5 \%$ to $6 \%$ divergence. These results indicate that CAV circulating in Egypt have marked variations with a commercial CAV vaccine (Nobilis ${ }^{\circledR}$ CAIV P4) as
Advances in Animal and Veterinary Sciences well as with old CAV isolated in 1990s and recent Egyptian viruses, Egy-1 and Egy-2 (AboElkhair et al., 2014).

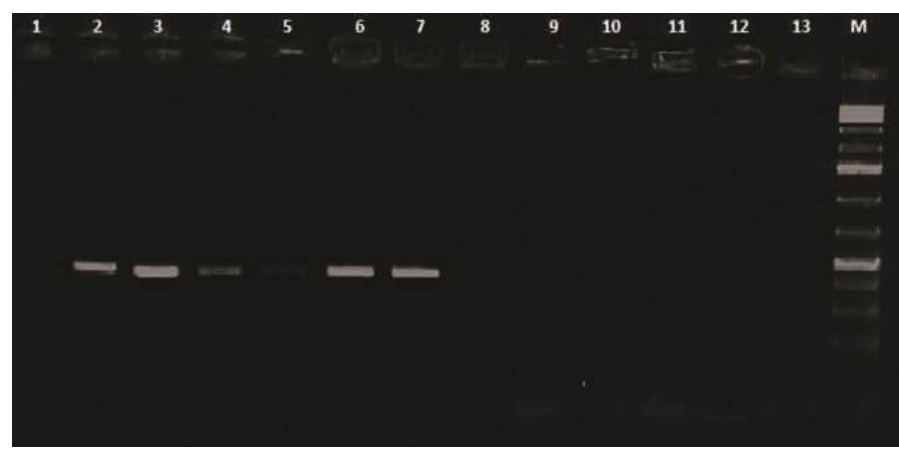

Figure 5: PCR products (418 bp) of amplified CAV-DNA extracted from tissues of diseased chicks;

Lanes 1 and 2: Control negative and positive respectively; Lane 3, 4, 5,6 and 7: Positive samples; Lanes 8 to 13: Negative; M: 100 base pairs ladder

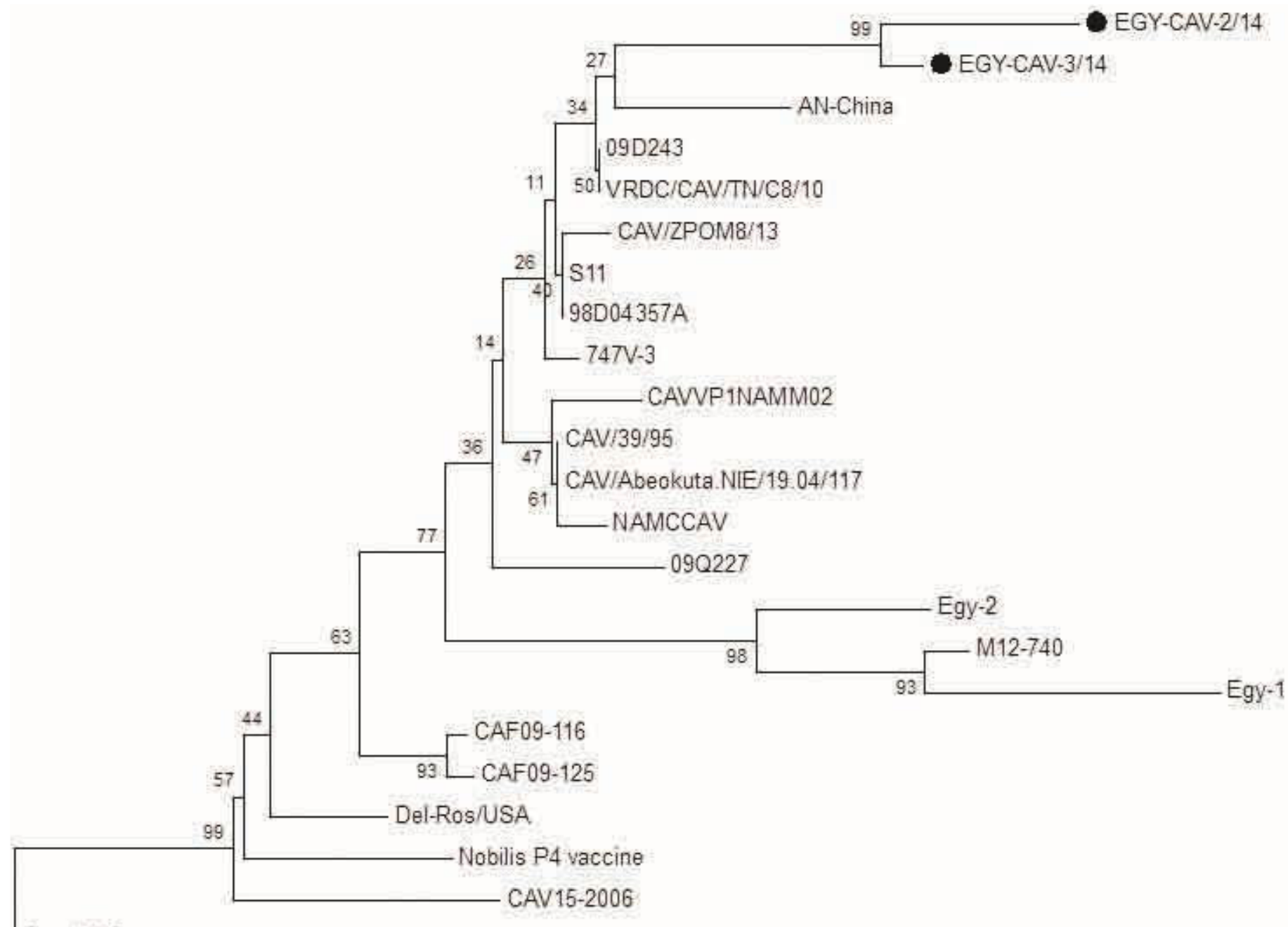

\section{Cux-1N/Germany}

Chicken anaemia agent

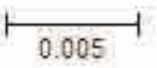

Figure 6: Phylogenetic tree for the 2 Egyptian CAV and other related CAV strains based on the partial VP1 gene sequence. The viruses used in this study were indicated by black dots 
Table 2: Nucleotide divergence of Egyptian CAV with other selected CAV viruses

$\begin{array}{lllllllllllllll} & \mathbf{1} & \mathbf{2} & \mathbf{3} & \mathbf{4} & \mathbf{5} & \mathbf{6} & \mathbf{7} & \mathbf{8} & \mathbf{9} & \mathbf{1 0} & \mathbf{1 1} & \mathbf{1 2} & \mathbf{1 3} \\ \text { CAVVP INAMM02 } & & & & & & & & & & & & & \\ \text { Nobils P4 vaccine } & 0.03 & & & & & & & & & & & & \\ \text { CAV 15-2006 } & 0.04 & 0.03 & & & & & & & & & & & \\ \text { M12-740 } & 0.03 & 0.05 & 0.06 & & & & & & & & & & \\ \text { AN-China } & 0.02 & 0.04 & 0.04 & 0 / 05 & & & & & & & & & \\ \text { Chicken anaemia agent } & 0.03 & 0.02 & 0.03 & 0.05 & 0.04 & & & & & & & & \\ \text { CAV/39/95 } & 0.01 & 0.03 & 0.03 & 0.03 & 0.02 & 0.03 & & & & & & & \\ \text { 09Q227 } & 0.02 & 0.03 & 0.04 & 0.04 & 0.03 & 0.03 & 0.01 & & & & & & \\ \text { NAMCCAV } & 0.01 & 0.03 & 0.04 & 0.04 & 0.02 & 0.03 & 0.00 & 0.02 & & & & & \\ \text { CAF09-125 } & 0.02 & 0.02 & 0.02 & 0.04 & 0.03 & 0.02 & 0.02 & 0.02 & 0.02 & & & & \\ \text { Egy-1 } & 0.05 & 0.06 & 0.07 & 0.02 & 0.06 & 0.06 & 0.05 & 0.05 & 0.05 & 0.06 & & & \\ \text { Egy-2 } & 0.03 & 0.05 & 0.05 & 0.02 & 0.04 & 0.05 & 0.03 & 0.04 & 0.03 & 0.03 & 0.04 & & \\ \text { EGY-CAV-2/14 } & 0.04 & 0.06 & 0.06 & 0.06 & 0.03 & 0.06 & 0.03 & 0.03 & 0.04 & 0.04 & 0.06 & 0.06 & \\ \text { EGY-CAV-3/14 } & 0.03 & 0.05 & 0.05 & 0.04 & 0.03 & 0.05 & 0.03 & 0.03 & 0.03 & 0.03 & 0.05 & 0.04 & 0.01\end{array}$

\section{DISCUSSION}

Chicken infectious anemia (CIA) is the disease of young chickens (Yuasa et al., 1979), which characterized by generalized lymphoid atrophy resulting in immunosuppression and severe destruction of erythrocytic and granulocytic series of the bone marrow cells, giving rise to aplastic anemia (Taniguchi et al., 1982, 1983; Yuasa et al., 1979). In the present study, the clinical signs and postmortem lesions are in agreement with findings of previous studies (Aly, 2001; Taniguchi et al., 1982, 1983; Yuasa et al., 1979). A case of yellowish changes in the bone marrow and thymic atrophy may be indicative to chicken anemia virus infection beside other means of diagnosis (Pope, 1991; Ramadan et al., 1998; Yuasa et al., 1979). The mortality rate is generally between $10-20 \%$, but may reach $60 \%$ especially in complicated cases (Gelderblom et al., 1989). In the present study, a wide variation in mortality from 3 to $31.25 \%$ was noticed in suspected cases. This variation in mortality may depend on many factors including synergistic effect of CAV and other diseases, poor hygiene condition, poor ventilation and low quality feed. The obtained results agreed with that previously mentioned by Chettle et al. (1989) who found mortality of $8.83-34.7 \%$ in commercial broilers, Hofstad et al. (1984) who reported mortality ranged from 1 to $50 \%$. Balachandran et al. (1991) have reported mortality of $12 \%$. Engstrom and Luthman (1984) who mentioned that mortality due to CIA alone was as high as $60 \%$, but usually it remained between $5-10 \%$. On the other hands, clinical signs of the disease, especially in chicks above 3 weeks were not seen, but lesions suggestive of CAV such as both lymphoid depletion and atrophy of thymus were recorded. These findings were compatible with that previously mentioned by Ledesma et al. (2001) who noticed that the chicks infected with virulence strain or high doses of virus after the decay of maternal antibodies suffered from lymphoid lesions without anemia. Moreover, the previous studies noticed the absence of clinical signs after about 3 weeks of age and that the immunocompetent chickens are resistant to disease, but they can acquire asymptomatic infections (Owoade et al., 2004; Schat, 2003). Histopathological examination of the affected chicks revealed generalized lymphoid aplasia in thymus, spleen, bursa and bone marrow; these findings were in agreement with those reported by previous investigators (Dhama et al., 2002; Smyth et al., 1993). The reported lymphoid aplasia could be clearly discussed by the potent immunosuppressive effect of CAV which induces marked destruction both to bone marrow stem cell and precursor T-lymphocytes in thymus (Goryo et al., 1989; Smyth et al., 1993), this immunosuppressive effect caused by apoptosis which induced by VP3 protein (apoptin) in both primary and secondary lymphoid organs. Thereby, destruction of the helper (CD4+) and cytotoxic (CD8+261) T-lymphocytes take place (Adair, 2000; Hu et al., 1993; Pope, 1991; Schat, 2003) leading to enhancement of the concurrent infection with other pathogens and vaccination failure (Adair, 2000). The apoptotic properties of CAV was confirmed in the present study by using in situ apoptotic TUNEL detection assay the obtained results revealed marked apoptosis of lymphocytes in all examined lymphoid tissues and of hepatocytes, this finding was in agreement with Shen et al. (2003) who reported that chicken anemia virus VP3 protein induced apoptosis in vitro and in vivo which confirmed by using of TUNEL assay. These results show that apoptosis, a phenomenon that has been observed for a few other viruses, is also an important phenomenon during the pathogenesis of CAV (Jeurissen et al., 1992). The serologic survey performed in this study involved 10 different localities of Behera province, 2 localities of Matrouh province and 1 locality of Kafr 
El-Sheikh province representing different breeds and ages to express as much as possible the field conditions. Bird's age was intended to exceed the age of 3 weeks to exclude maternally derived immunity that persists for about 3 weeks (McNulty et al., 1988). The overall serological findings of this study proved that CIAV is widely distributed in commercial broiler flocks (with percentage of $85 \%$ \& ELISA titters ranging from 53 to 13878). Such results agree with the earlier findings of the previous surveys conducted in Egypt, Islam (2003) reported that seroprevalence was $74.6 \%$ in commercial broiler in Sharkia province. While, Hegazy et al. (2010) reported that seroprevalence was $87.78 \%$ in broiler flocks in Sharkia province. The seroprevalence was $86 \%$ in commercial broiler flocks in Nigeria (Owoade et al., 2004), 87.7\% in commercial broiler flocks in Shahrekord, Iran (Mahzounieh et al., 2005), 82.61\% in commercial broiler flocks in Northern Jordan (Dergham, 2006). PCR has the major advantage of providing a faster and sensitive detection of more fastidious viral pathogens that might require several days and consecutive passages in cell culture for virus isolation and allowing the fast in vitro diagnosis of viruses that may not be readily isolated by in vitro cell culture (Cavanagh, 2002; Dhama et al., 2002). PCR assay performed on the extracted DNA from tissues of diseased birds yielded positive reactions with correct size 418 bp (Hussein et al., 2002) in 65\% of investigated broiler chicken flocks indicating that these signs and lesions are due to CIAV infection. In all PCR positive flocks, the thymus, liver, bursa of Fabricius and spleen collective samples were positive; this is probably because CAV targets erythroid and lymphoid progenitor cells in the bone marrow and thymus respectively (Adair, 2000). The obtained result revealed the detection of CAV DNA in $65 \%$ of tissues of investigated broiler chicken flocks and agreed with Mohamed (2010) who detected CAV DNA from 44 field samples out of 165 suspected broiler chickens of age up to 7 weeks with a percentage $26.6 \%$ and Hegazy et al. (2010) who detected CAV DNA from 3 field samples out of 4 suspected cases with a percentage $75 \%$. While, disagreed with Chowdhury et al. (2002) who detected CAV DNA from 5 field samples out of 125 suspected cases with a percentage $4 \%$. The phylogenetic analysis in this study for the 2 Egyptian CAV indicate their grouping in one group very close to other viruses from China and Middle East, they are distinct from recent viruses from Egypt and other viruses from Africa like Central African Republic viruses. These results indicate that circulating CAV in Egypt showed marked variation with old CIAV isolated in 1990s, recent Egyptian CIAV isolated in 2014s and with the vaccine strain (Nobilis ${ }^{\circledR}$ CAIV P4). Further studies are needed to investigate the situation and to compare the 304 antigenic matches with currently used vaccines. Several facts suggest that the incriminated agent in this study is the chicken infectious anemia virus $(\mathrm{CAV})$ including the observed clinical signs, postmortem lesions, histopathological and immunohistochemical findings and PCR detection of DNA fragments of CAV genome of correct size as primers used (418bp). The origin of the CAV present in the studied chickens may be due to vertically infected birds with CAV. Bülow and Schat (1997) reported CAV even in the presence of high neutralizing antibodies titers and Imai et al. (1999) suggesting that the virus may persist in the presence of antibodies. In addition, live vaccines produced with $\mathrm{CAV}$, contaminated eggs and cells may have played a role in the dissemination of CAV to chickens due to the previously undetected CAV infection in SPF flocks (Barrios et al., 2009).

\section{CONCLUSION}

We concluded that CAV is widely distributed among investigated commercial broiler flocks in these three provinces. In addition, the presence of clinical form of CAV infection was confirmed by using PCR. Both clinical and subclinical forms of CAV infection have destructive effect on lymphoid organs leading to immunosuppression and subsequently vaccination failure, complications with other pathogens, and great economic losses. The obtained results indicated that circulating CAV in Egypt showed marked variation with old CAV isolated in 1990s and recent Egyptian CAV isolated in 2014 with the vaccine strain (Nobilis ${ }^{\circledR}$ CAIV P4). Further studies are needed to investigate the situation and to compare the antigenic match with currently used vaccines in breeder's immunization regimens so as to advise suitable prevention strategies for this economically important avian viral disease pathogen.

\section{ACKNOWLEDGMENTS}

The authors thank the Reference Laboratory for Veterinary Quality Control on Poultry Production for help in samples collection.

\section{CONFLICT OF INTEREST}

Authors have no conflict of interest.

\section{AUTHORS' CONTRIBUTION}

EH, AA and NA collected samples, applied the serological analysis of samples and wrote manuscript. AK searched and performed histopathological and immunohistochemical analysis and wrote the relevant parts of the manuscript. All the authors read and approved the manuscript.

\section{REFERENCES}

- AboElkhair M, Abd El-Razak AG, Metwally AY (2014). 
Molecular characterization of Chicken Anemia Virus Circulating in Chicken Flocks in Egypt. Adv. Virol. Article ID 797151, 797156 pages. http://dx.doi. org/10.1155/2014/797151

-Adair B (2000). Immunopathogenesis of chicken anemia virus infection. Develop. Compar. Immunol. 24: 247 - 255. http:// dx.doi.org/10.1016/S0145-305X(99)00076-2

-Aly M (2001). Isolation of chicken infectious anemia virus from outbreaks in broilers chickens in Egypt. J. Egyptian Vet. Med. Assoc. 61(6): 137 - 147.

-Balachandran C, Muralimanohar B, Sundararaj A, Thanickachalam M (1991). Infectious bursal disease and its association with gangrenous dermatitis in Tamil Nadu. Int. Vet. J. 68: 718-720.

-Bancroft J, Steven A, Turner DR (1996). Theory and practice of histological techniques (Livingstone Churchill Ed. 4th edition ed.). Melbourne, New York.: Edinburgh, London.

-Barrios P, Marin SY, Resende M, Rios RL, Resende JS, Horta RS, Martins NRS (2009). Occurrence of chicken anemia virus in backyard chickens of the metropolitan region of belo horizonte, Minas Gerais. Brazil. J. Poult. Sci. 11: 135-138.

-Biilow V, Rudolph R, Fuchs B (1986). Erhöhte Pathogenität des Erregers der aviären infektiösen Anämie bei Hühnerküken (CAA) bei simultaner Infektion mit dem Virus der Marekschen Krankheit (MDV), Bursitisvirus (IBDV), oder Reticuloendotheliose virus (REV). J. Vet. Med. 33: 93-116. http://dx.doi.org/10.1111/j.1439-0450.1986.tb00010.x

-Bülow V, Schat KA (1997). Chicken infectious anemia In W Ames Calnek B, J Barnes H, CW Beard, R McDougald L , M Saif Y (Eds.), Diseases of poultry (10th ed ed., pp. 739756): Iowa State University Press.

- Cavanagh D (2002). Innovation and discovery: The application of nuclic acid-based technology to avian virus detection and characterization. Avian Pathol. 30: 581-593. http://dx.doi. org/10.1080/03079450120092071

- Chettle N, Eddy RK, Wyeth PJ, Lister SA (1989). An outbreak of disease due to chicken anaemia agent in broiler chickens in England. Vet. Record. 124: 211-215. http://dx.doi. org/10.1136/vr.124.9.211

- Chowdhury S, Omar AR, Aini BM, Hair AA (2002). Isolation, identification and characterization of chicken anaemia virus in Malaysia. J. Biochem. Mol. Biol. Biophysiol. 6: 249-255.

- Craig M, Rimondi A, Delamer M, Sansalon P, Konig G, Vgnozzi A, Pereda A (2009). Molecular characterization ofchicken infectious anemia virus irculating in Argentina during2007. Avian Dis. 53: 331-335. http://dx.doi.org/10.1637/8478100808-Reg.1

-Dergham A ( 2006). Serological survey on the prevalence of chicken infectious anemia virus in commercial broiler chicken flocks in northern Jordan. Int. J. Poult. Sci. 6: 544 - 546 .

-Dhama K, Kataria JM, Dash BB, Kumar NS, Tomar S (2002). Chicken Infectious Anemia- A review. Indian J. Compar. Microb. Immunol. Infect. Dis. 23: 1-15.

-Ducatez MF, Chen H, Guan Y, Muller CP (2008). Molecular epidemiology of chicken anemia virus (CAV) in southeastern Chinese live birds markets. Avian Dis. 52: 68-73. http:// dx.doi.org/10.1637/8049-070407-Reg

-Ducatez MF, Owoade AA, Abiola JO, Muller CP (2006). Molecular epidemiology of chicken anemia virus in Nigeria. Arch. Virol. 151: 97-111. http://dx.doi.org/10.1007/ s00705-005-0609-7

-El-Lethi A (1990). Viral contamination of dressed poultry.
(M.V.Sc. Thesis), Cairo University, Egypt .

-Engstrom B, Luthman M (1984). Blue wing disease of chickens: Signs, pathology and natural transmission. Avian Pathol. 13: 1-12. http://dx.doi.org/10.1080/03079458408418503

-Gelderblom H, Kling S, Lurz R, Tischer I, Bülow VV (1989). Morphological characterization of chicken anemia agent (CAA). Arch. Virol. 109: 115 - 120. http://dx. doi. org/10.1007/BF01310522

- Goryo M, Hayashi S, Yoshizawa K, Umemura T, Itakura C, Yamashiro S (1989). Ultrastructure of the thymus in chicks inoculated with chicken anemia agent (MSB1TK5803 strain). Avian Pathol. 18: 605-617. http://dx.doi. org/10.1080/03079458908418581

- Goryo M, Shibata Y, Suwa T, Umemura T, Itakura C (1987). Outbreak of anaemia associated with chicken anaemia agent in young chicks. Japan. J. Vet. Sci. 49: 867-868.

-Gravrieli Y, Sherman Y, Ben-Sasson S (1992). Identification of programmed cell death in situ via specific labeling of nuclear DNA fragmentation. J. Cell Biol. 119: 493-501. http:// dx.doi.org/10.1083/jcb.119.3.493

-Hegazy A, Abdallah FM, Abd-El Samie LK, Nazim AA (2010). Chicken Infectious Anemia Virus (CIAV) in Broilers and Laying Hens in Sharkia Province, Egypt. J. Am. Sci. 6(9): 752-761.

-Hofstad M, Barnes HJ, Calnek BW, Reid WM, Yoder Jr HW (1984 ). Diseases of poultry (8th Ed ed.). USA: Iowa State Univ. Press Ames Iowa.

-Hu L, Lucio B, Schat KA (1993). Depletion of CD4+ and CD8+ T lymphocytes subpopulations by CIA-1, a chicken infectious Anemia virus. Avian Dis. 37: 492-500. http:// dx.doi.org/10.2307/1591677

-Hussein H, Sabry MZ, El-Ebiary EA, El-Safty M, AbdelHady AL (2002). Chicken infectious anemia virus in Egypt: Molecular diagnosis by PCR and isolation of the virus from infected flocks. Ar. J. Biotech. 5(2): 263 - 274.

-Imai K, Mase M, Tsukamoto K, Hihara H, Yuasa N (1999). Persistent infection with chicken anemia virus and some effects of highly virulent infectious bursal disease virus infection on its persistency. Res. Vet. Sci. 67: 233-238. http:// dx.doi.org/10.1053/rvsc.1999.0313

-Islam M, Johne R, Raue R, Todd D, Muller H (2002). Sequence analysis of the full-length cloned DNA of a chicken anemia virus (CAV) strain from Bangladesh: evidence for genetic grouping of CAV strains based on the deduced VP1 amino acid sequences. J. Vet. Med. 49: 332-337. http://dx.doi. org/10.1046/j.1439-0450.2002.00581.x

-Islam T (2003). Serological studies on chicken infectious anemia virus in Sharkia governorate. . (M. V. Sc. Thesis), Zagazig University faculty of veterinary medicine.

- Jeurissen S, Wagenaar F, Pol JM, Van der EA, Noteborn MH (1992). Chicken anemia virus causes apoptosis of thymocytes after in vivo infection and of cell lines after in vitro infection. J. Virol. 66 (12): 7383-7388.

-Kim H, Kwon YK, Bae YC, Oem JK, Lee OS (2010). Molecular characterization of chicken infectious anemia viruses detected from breeder and broiler chickens in South Korea. Poult. Sci. 89: 2426-2431. http://dx.doi.org/10.3382/ ps.2010-00911

-Ledesma N, Fehervari T, Casaubon MT, Lucio E, Ratz F (2001). Chicken infectious anemia in Mexico: virus identification and serology survey. Avian Dis.. 45: 788-796. http://dx.doi. org $/ 10.2307 / 1592858$

-Lucio B, Schat KA, Shivaprasad HL (1990). Identification of 
thechicken anemia agent,reproduction of the disease and serologicalsurvey in the United States. Avian Dis. 34 146153. http://dx.doi.org/10.2307/1591346

-Mahzounieh M, Karimi I,Zahraei ST (2005). Serologic evidence of chicken infectious anemia in commercial chicken flocks in Shahrekord. Iran. Int. J. Poult. Sci. 4 (7): 500 - 503. http:// dx.doi.org/10.3923/ijps.2005.500.503

-McConnell C, Adair BM, McNulty MS (1993). Effects of chicken anemia virus on cell-mediated immune function in chickens exposed to the virus by a natural route. Avian Dis. 37: 366-374. http://dx.doi.org/10.2307/1591660

-McNulty M, Mcllroy SG, Bruce DW, Todd D (1991). Economic effects of subclinical chicken anemia agent infection in broiler chickens. Avian Dis. 35: 263-268. http://dx.doi. org/10.2307/1591175

-McNulty MS, Connor TJ, McNeilly F, Kirkpatrick KS, McFerran JB (1988). A serological survey of domestic poultry in the United Kingdom for antibody to chicken anemia agent. Avian Pathol. 17: 315 - 324. http://dx.doi. org/10.1080/03079458808436450

-Mohamed M (2010). Chicken infectious anemia status in commercial broiler chickens flocks in Assiut-upper Egypt: Occurrence, molecular analysis using PCR-RFLP and apoptosis effect on affected tissues. Int. J. Poult. Sci. 9 (6): 591-598. http://dx.doi.org/10.3923/ijps.2010.591.598

- Natesan S, Kataria M, Dhama K, Rahul S, Baradhwaj N (2006). Biological and molecular characterization of chicken anemia virusisolates of Indian origin. Virus Res. 118: 78-86. http:// dx.doi.org/10.1016/j.virusres.2005.11.017

- Noteborn M, DeBoer GF, Van Roozelaar DJ, Karreman C, Kranenburg O, Vos JG, J Van der EBA (1991). Characterization of cloned chicken anemia virus DNA that contains all elements for the infectious replication cycle. J. Virol. 65: 3131-3139.

- Noteborn M, Todd D, Verschueren CAJ, De Gauw HWF, Curran WL, Veldkamp S, Koch G (1994). A single chicken anemia virus protein induces apoptosis. J. Virol. 68: 346-351.

- Noteborn M, Verschueren CA, Koch G, Van Der AJ (1998). Simultaneous expression ofrecombinant baculovirusencoded ChickenAnaemia Virus (CAV) proteins VP1 and VP2 isrequired for formation of the CAV-spedficneutralising epitope. J. Gen. Virol. 79: 3073-3077. http://dx.doi. org/10.1099/0022-1317-79-12-3073

- Oluwayelu D, Todd D, Ball NW, J Scott AN, Oladele OA, Emikpe BO, Olaleye OD (2005). Isolation and preliminary characterization of chicken anemia virus from chickens in Nigeria. Avian Dis.49: 446-450. http://dx.doi. org/10.1637/7339-020705R.1

- Owoade A, Oluwayelu DO, Fagbohun OA, Ammerlaan W, Mulders MN, Muller CP (2004). Serologic evidence of chicken infectious anemia in commercial chicken flocks in southwest Nigeria. . Avian Dis. 48(1): 202 - 205. http:// dx.doi.org/10.1637/7075

-Peters M, Crabb BS, Browning GF (2001). Chicken anaemia virus VP2 is a novel protein tyrosine phosphatase. Paper presented at the 2 nd International Symposium on Infectious Bursal Disease and Chicken Infectious Anaemia, Giessen, Germany.

-Pope C (1991). Chicken anemia agent. Vet. Immunol. Immunopathol. 30(1): 51-65. http://dx.doi. org/10.1016/0165-2427(91)90008-Z

-Pringle C (1999). Virus taxonomy at the XI International Congress of Virology, Sydney, Australia. . Arch. Virol. 144:

\section{5-2070. http://dx.doi.org/10.1007/s007050050728}

- Ramadan G, El-Hussini H, Bekhit A (1998). Biochemical and hematological characterization of chicken anemia virus (CAV). Assuit Vet. Med. J. 38(76): 209 - 222.

-Sabry M, Khafagy AK, Hanna E1-Samadony A, El-Mahgoub KM. (1998). A sero epidemiological survey of meatand egg- type chickens in Egypt for antibody to chicken infectious anaemia virus. Paper presented at the Procceding 5th. Scientific Conference Egypt.

-Schat K (2003). Chicken Infectious Anemia. . In M Saif Y, G Barnes H, R Glisson J, M Fadly A, R McDougald L , E Swayne D (Eds.), Disease of Poultry (11th ed ed., pp. 182). USA: Iowa State University. Press, Ames.

- Senthilkumar N, Govindarajan D, Dhama K, Kataria JM (2002). Chicken anemia virus: An emerging threat to Indian poultry industry. Pashudhan: 17: 13.

-Shen Z, Wang Y, Zong Y, Qu S (2003). Experimental study on the antitumor effect of chicken anemia virus vp3 gene against liver carcinoma in vivo. J. Huazhong Uni. Sci. Technol. Med. Sci. 23(2): 105-107, 115.

- Smyth J, AM, McNulty MS, Todd D, Mackie DP (1993). An equential histopathologic and immunocytochemical study of chicken anaemia virus infection at one day of age. Avian Dis. 37: 324-338. http://dx.doi.org/10.2307/1591656

-Snoeck C, Komoyo GF, Mbee BP, Nakoune E, Le Faou A, Okwen MP, Muller CP (2012). Epidemiology of chicken anemia virus in Central African Republic and Cameroon. .J. Virol. 9: 189. http://dx.doi.org/10.1186/1743-422X-9-189

- Taniguchi T, Yuasa N, Maeda M, Horiuchi T (1982). Hematopathological changes in dead and moribund chicks induced by chicken anemia agent. National Institution of Animal Health Q.22: 61 - 69.

- Taniguchi T, Yuasa N, Maeda M, Horiuchi T (1983). Chronological observations on hemato-pathological changes in chicks inoculated with chicken anemia agent. National Institution of Animal Health Q. 23: 1 - 12.

-Todd D (2000). Circoviruses: Immunosuppressive threats to avian species: A review. Avian Pathol. 29: 373-394. http:// dx.doi.org/10.1080/030794500750047126

- Van Den Berg T (1996). Immunodepressive viral diseases in poultry: Current situation and perspectives. Poult. Advisor. $17-25$.

-Yuasa N, Imai K (1986). Pathogenicity and antigenicity of eleven isolates of chicken anaemia agent (CAA). Avian Pathol. 15: 639-645. http://dx.doi.org/10.1080/03079458608436327

-Yuasa N, Imai K, Watanabe K, Saito FMA, Komi K (1987). Aetiological examination of an outbreak of haemorrhagic syndrome in a broiler flock in Japan Avian Pathol. 16: 521526.

-Yuasa N, Taniguchi T, Yoshida I (1979). Isolation and some characteristics of an agent-inducing anemia in chicks. Avian Dis. 23: 366 - 385. http://dx.doi.org/10.2307/1589567

-Zaki A, El-Sanousi AA (1994). Chicken anemia agent in Egypt: A serological survey of antibody against chicken anemia agent in some commercial chicken flocks using indirect immunofluorescent technique. Vet. Med. J. Giza. 24(3): $53-58$. 